\title{
GAP ANALYSIS OF TRAVELOKA.COM: HOTEL CONSUMERS' EXPECTATIONS AND PERCEPTIONS OF THE WEBSITE
}

\author{
Fransisca Andreani*1, Gabriella Winata ${ }^{2}$, Eunike Halim ${ }^{3}$ \\ ${ }^{123}$ Hotel Management Program, Petra Christian University, Siwalankerto 121-131, Surabaya 60236, Indonesia \\ *Corresponding author; Email: andrea@petra.ac.id
}

\begin{abstract}
Traveloka.com is one of the famous online travel agents to make hotel reservation in Indonesia. Consumers making online hotel reservation can sometimes find that the performance of the website does not meet their needs. This study is to analyze the gap between hotel consumer expectations and perceptions on the website dimensions of traveloka.com. It is a quantitative method with 150 respondents who made hotel reservations through traveloka.com. The analysis techniques used are mean test and paired $t$-test. The results show that there are significant gaps between consumer expectations and perceptions on the website dimensions of traveloka.com. The biggest gap is on the images displayed which are in accordance with the real conditions.
\end{abstract}

Keywords: Expectations, perceptions, gap, website, traveloka.com.

\section{Introduction}

Internet has become the most important media of communication nowadays, especially in making hotel reservations. In the past, consumers reserved hotels via travel agents, by phone or even they came directly to hotels. But now they can reserve hotels without spending too much time and efforts by visiting Online Travel Agents (OTA) via their websites. According to Huizingh (2000), a website consists of two dimensions: content (company background, specific products, non-commercial information, transaction, entertainment, advanced site and perceived content) and design (navigation structure, search function, protected content, quality of navigation structure, image, and presentation style). A good website should have all of these features.

Expedia.com, traveloka.com, tiket.com, agoda. com, booking.com are some of famous OTAs in Indonesia. Compared with tiket.com, traveloka.com is more famous as it has a lot more visitors (Cosseboom, 2015). Hartono (2015) states that consumers need to wait longer to access hotel lists and rates from tiket.com than from traveloka.com. Besides that, consumers usually find some errors while making payment in tiket.com. Thus, it makes traveloka.com more user friendly. On the other hand, according to Erwinpetas (2015) tiket.com is more superior in view of the supplied product ranges and the reward given. Traveloka.com only provides airline tickets and hotels, while tiket.com provides other products, such as train tickets, car rentals, as well as other tickets for certain events. In terms of rewards given, tiket.com provides program points that can be accumulated and redeemed for hotel and ticket discounts. Such rewards are not available in traveloka.com.

A study by Law and Hsu (2015) in China shows that most consumers find some discrepancies in the content of the website with consumer needs. In China, websites are widely used as a means to find information for travelling or business purposes. So websites should provide content that corresponds with the needs of consumers.

According to Anandhita, Kertahadi and Suyadi (2014), the design of a website is very influential on increasing sales. However, some websites in Indonesia are considered less user friendly as they tend to be a little bit complicated and slow in response due to large paper size. Based on this phenomenom, the writers would like to analyze if there are significant gaps between hotel consumer expectations and perceptions on the website dimensions of traveloka.com. Expectations refer to what consumer needs or wants before making online hotel reservation; whereas perceptions refer to consumer experiences after making online reservations. The purpose of this study is to analyze whether there are significant gaps between consumer expectations and perceptions on traveloka.com.

\section{Consumer Expectations Versus Consumer Perceptions}

Consumer expectations refers to consumer standards or needs before buying goods or services (Lovelock \& Wright, 2007). Successful companies are the 
ones which are able to provide goods or services according to customer needs and wants (Kotler \& Keller, 2006). Horovitz (2000) states that expectations can be formed by four factors as follows:

1. Communications by service providers

Service providers compete with each other to communicate their services to consumers. One of them is by giving promises through advertising and other media that will eventually inflict consumer hopes

2. Price paid

The greater amount of money is spent by consumers, the greater consumer expectations are to be satisfied with goods or services offered by the service providers.

3. Past experience

If a consumer has ever satisfied with goods or services offered by a service provider, he or she tends to expect the same experience he or she has ever had while consuming the same goods or services.

4. Similar experience

When a consumer feels satisfied with the given service, he or she will recommend his or her experience to his friends and others to consume the service and hope that others will have the same experience as his or hers.

Moreover, perceptions refer to a process in which a consumer choose, organize and interpret some information to be used to describe something. It does not depend on physical stimuli but also other stimuli related with the surroundings and individual circumstances. Perceptions can be one of some factors affecting consumer behavior (Kotler 2009). According to (Kotler, 2009), perceptions are formed in the following process:

1. Selective attention

Consumers filter messages based on their needs, interests and expectations.

2. Selective distortion

Consumers tend to transform information in their personal sense and interpret it in a way that supports their perception.

3. Selective retention

Consumers will forget things they learn easily but remember information that supports their views and beliefs.

A gap occurs when there are discrepancies between what is expected (expectations) with what is received (perceptions) when consuming a product or service. Zeithaml, Bitner and Gremler (2009) stated that consumers are dissatisfied when what is expected is less than what is received. When what is expected is the same as what is received, consumers are satisfied. Furthermore, when consumer perceptions are greater than their expectations, it can be said that consumers are delighted.

\section{Online Hotel Reservation}

Reservation is derived from reserve meaning message. According to Kamus Besar Bahasa Indonesia Online (2015, para.1), it refers to a process, act of ordering or booking. While, according to English Oxford Dictionaries Living (2016), it refers to set or get something in the future. Online Reservation is done directly by consumers through the websites of service providers (Ratnasingam, 2012) . It is one way to give better service quality to their consumers (Bakar \& Hashim, 2008). Janal (2005) suggests some benefits of having online reservations through websites are as follow:

1. Convenience/ Ease of bookings

Consumers can buy or book a product or service any where and any time.

2. Information

A website usually provides product or service information, like price and product specification.

3. Respond to market condition

Service providers can add new products or services with their specific information easier and faster.

4. Price reduction

By using a website, promotion fee becomes cheaper as service providers do not need to rent or have a store, equipments and insurance. On the other hand, consumers can get better price as they can compare one service provider with the other.

5. Fewer hassles

Consumers do not need to have face to face interaction with service providers which may push them to buy the product or service.

However, the greater use of online reservations through websites may also have some limitations (Wearne \& Baker, 2002), which are:

1. Uneven spread of the internet

Demographic segment influences internet users. Most of internet users are young people, older people do not use internet as much as young people.

2. System crashing

Online reservation is based on a system. When this system is disrupted, it can cause negative impacts for consumers, like double transaction, double booking and so forth. The ones affecting the 
system disruption are network or server dysfunctionality, bug, and inadequate devices.

3. Security

Consumer important information, like credit card names, credit card numbers, addresses and so on, must be kept confidentially. Otherwise, hackers might misuse this information that can harm not only consumers but also service providers themselves.

\section{A Website}

A website consists of one or more pages having interconnecting information at random with one another (Nykiel, 2011). It can be managed easily in the form of a hierarchy that can be developed from general information into more specific and complicated information. Huizingh (2000) states that a good website should have dimensions with the following criteria:

1. Content of a website refers to the following website's features.

a. Company background contains information about a company's vision, mission, financial statements, a list of important customers and an overview of completed projects. It is important to present this information to potential consumers as well as to other stakeholders.

b. Specific products refer to products or services' information like price, specifications, terms of delivery, and animations of products or services.

c. Non-commercial information may relate to supporting information like company's sponsored events or new technologies, its geographical location, For a hotel, it may offer information of nearby tourist attractions and museums.

d. A facility to request for proposals contains list of products or services and prices to be purchased by consumers. This direct transaction may look simple but in a more complex situation, consumers and service providers will have to interact several times before all details in the order have been agreed upon.

e. Direct ordering refers to all details in the transaction (like total amount of products/ services and prices) made by consumers in online purchase.

f. Entertainment may relate to features used in a website that may attract consumers and can be used as a media of communication, such as jokes, cartoons, pictures, games, and video clips. g. Advanced site features refer to the fact that the more available features in the website, the more advanced the website will be. The extent to which a website is advanced has been measured with the number of different features it contains. So if the website contains all six features (a up to f) mentioned earlier, it is considered as an advanced site.

2. Design of a website should provide ease use for consumers to get needed information. It includes the followings:

a. Navigation structure is divided into a hierarchical and network structures. In a hierarchical or tree structure, a page is linked to one or more pages at the next level and to only one page at the previous level. Whilst in a full network structure, a page is linked to all other pages in the website. Thus, it enables consumers to navigate as they wish to get the needed information. However, the best structure is between a tree and a full network.

b. Search function can ease consumers to get the requested information directly by entering key words. It helps consumers to find specific information within the site (not the entire web).

c. Protected content are pages only for consumers that are protected by means of an Internet Protocol (IP) address and password. So different consumers will have different IP addresses and passwords to request information.

d. Quality of the navigation structure is to ease and make consumers feel comfortable to access the website.

e. The image of a website refers to how interesting it is in the eyes of the consumers. This can include choices of words displayed in the web, pictures or photos, videos as well as other cartoons or animations.

f. The presentation style should stimulate not only reading, listening and viewing but also facilitating the interpretation of the information which includes lay outs, colors, font style and size, and placement of links.

\section{Previous Studies}

An explorative study is done by Law and Hsu (2005) to find some important dimensions and attributes of accessing a hotel website. The important dimensions include information about reservation, contacts, hotel facilities, website management and tourist attractions near the hotel. Whereas, the important attributes are room rates, payment methods, safety of transaction, hotel descriptions, room facilities, 
contact numbers, address, search function and the like. The results of the study show that the most important dimension is information about reservation and the most important attribute is room rate.

Another research by Phelan, Christodoulidou and Countryman (2011) tried to analyze the impact of a website on purchase intention involving twenty eight respondents. The results show that purchase intention is influenced by several factors like website's aesthetics (e.g. pictures on the website), ease of use (user friendly), colors, availability of the links, neat and unique look of the website.

In addition, Febrianti, Setyawan, and Thio (2007) did a study to find some gaps between consumer expectations and perceptions on the websites of five-star hotels in Surabaya using a descriptive analysis.The gaps include the information of hotel facilities, contact person, reservation, tourist attractions near the hotels and website management.

Using a factor analysis, Gozzali (2013) also made a research to find factors affecting consumers to make online hotel reservation in Surabaya. The results show that there are seven new factors that encourage consumers in making online reservation: popularity and technology, reliability, convenience, speed, information, price and reward. Among others, popularity and technology become the factor that contributes the most.

Finally Sosiawan and Shandika (2015) have also analyzed website dimensions influencing consumer purchase intention in making online hotel reservation in Surabaya. The writers use a quantitative descriptive analysis with 349 respondents. The study reveals eight new factors affecting consumers in making online reservation, which are access, safety and privacy, marketing, navigation, clarity of information, personalilzation, service, and accuracy. The most contributing factor is access.

\section{Research Method}

This study is a quantitave descriptive with popolation of those consumers who have ever made online hotel reservation through traveloka.com. The population in this study is infinite population so nonprobability sampling is used with judgemental sampling. With $10 \%$ margin of error for infinite population, the respondents must be at least 97; but the total number of respondents in this study is 150 .

A five point of Likert scales is used in the study from 1 (strongly disagree) to 5 (strongly agree) to see consumer expectations and perceptions. Then, data are analyzed using validity test, reliability and normality tests. Validity test is used to see the precision of the measuring instruments in the reseacrh. An instrument is valid when its correlation coefficient is greater than 0.30 . Reliability test is to measure the consistency and accuracy of measurement tools. It is said to be reliable when the value of Cronbach Alpha is greater than 0.70 . Normality test is also used to see whether data distribution is normal or not. It is said to be normal when A symp. Sig is greater than 0.05 .

Statictic descriptive analyses like mean, four scales of interval from very bad (less than 2.00) to very good (greater than 4.00), and paired sample $t$ test are also used to see the significant gaps with the help of SPSS 23.0. To determine the significant gaps, statistical critical value of $t$ is taken into consideration. When the value of $t$ obtained is less than 0.05 , the null hypothesis is rejected and the alternative hypothesis is accepted.

\section{Results and Discussion}

Thirty samples are taken to find whether the items in the questionnaires are valid and reliable. From data analysis, all items in the questionnaires have correlation coefficients which are greater than 0.30 . Thus, all items are valid. In addition, the values of Cronbach Alpha of consumer expectations (0.97) and perceptions (0.89) are greater than 0.70 . So, they are also reliable. From normality test, the value of $A$ symp. Sig is 2.00 which is greater than 0.05 . So it is said that data has normal distribution. In addition, the gaps between consumer expectations and perceptions can be seen in Table 1.

Table 1 shows that mean indicators in consumer expectations are all greater than 4.00 which are very good. While mean indicators in consumer perceptions are only seven which are greater than 4.00 , the other five indicators (better price, information about point of interests, distances from the hotel, interesting images, and images in accordance with the real condition) are ranged from 3.00 to 4.00 . Thus, they are considered as good enough. At the average, the means of consumer expectations and perceptions are greater than 4.00 so they are still considered as very good.

Furthermore, Table 2 below shows the result of Paired Samples $t$ test in which the significance is 0.000 (less than 0.050). So it can be said that there are significant differences/gaps between consumer expectations and perceptions and the hypothesis is accepted.

Most of the respondents in this study are between 18 to 27 years old (60\%) as older people do not use internet as much as young people. 
Table 1

Gaps between Consumer Expectations and Perceptions

\begin{tabular}{lccc}
\hline & Mean of & Mean of \\
\cline { 2 - 4 } & Expectation & Perception & Gap \\
\hline Traveloka.com offers better price compared to other online travel agents. & 4.39 & 3.93 & -0.46 \\
Hotel description and addresses can be found in Google Maps or Waze. & 4.51 & -0.50 \\
Information about hotel facilities are very complete. & 4.53 & -01 & -0.48 \\
Information about points of interests near the hotels is very & 4.43 & 3.87 & -0.56 \\
complete. & & \\
Information about distances from hotels to points of interest is accordance & 4.43 & 3.94 & -0.49 \\
with the actual distances. & & \\
Traveloka.com provides many kinds of payment (credit card, transfer, & 4.54 & 4.22 & -0.32 \\
etc.) & & \\
Steps and payment process are very easy. & 4.55 & 4.15 & -0.40 \\
Total Mean of Content & 4.48 & 4.02 & -0.46 \\
& & \\
Search box eases consumers to get the needed information. & 4.42 & 4.09 & -0.33 \\
Fast online reservation system makes consumers comfortable. & 4.51 & 4.17 & -0.34 \\
Traveloka.com eases consumers to get the necessary information. & 4.51 & 4.21 & -0.30 \\
Images in the website are interesting. & 4.21 & 3.90 & -0.31 \\
Images in the website are in accordance with the real condition & 4.42 & 3.73 \\
Total Mean of Design & 4.41 & 4.02 & -0.69 \\
\hline
\end{tabular}

Table 2

Paired Samples $t$ Test

\begin{tabular}{llccc}
\hline \multicolumn{1}{c}{ Pair } & Mean & $\boldsymbol{t}$ & $\boldsymbol{d f}$ & Sig. (2-tailed) \\
\hline $\begin{array}{l}\text { Consumer Expectations and } \\
\text { Perceptions }\end{array}$ & 0.432 & 12.447 & 11 & 0.000 \\
\hline
\end{tabular}

This is in line with Wearne and Baker (2002) who state that internet users are influenced by demography segments. Older people rarely use or do not use internet as much as young people. Mostly also work as private employees $(51 \%)$. Their monthly income is between $\mathrm{Rp} 2,000,001.00$ to $\mathrm{Rp}$ $4,000,000.00(38 \%)$ with average expenditure about Rp 400,001.00 to Rp 800,000.00 per transaction. As room rates of two to three star hotel in Indonesia is between $\operatorname{Rp~400,000.00~to~Rp~800,000.00,~it~can~be~}$ said that most respondents make online reservations in these hotels.

Table 1 reveals that seven indicators of content are very good. Consumers have a very high expectation in finding complete information about payment steps and process when making transaction with traveloka.com (mean 4.54). This is due to the fact that most consumers want to have easy payment access accordingly. Moreover, consumers have least expectation in the indicators of design, especially interesting images on traveloka.com (mean 4.21). They think that attracting images won't be able to guarantee the real condition of the hotel rooms or facilities. They are more concerned with the suitability of the images and the real condition of the hotel than the attractiveness of the images themselves. But as a whole, consumers have very high expectations in accessing traveloka.com as the average mean is greater than 4.00.

In terms of perceptions, consumers have good perceptions of the website traveloka.com as the means of five out of twelve indicators (offering better price, complete information about points of interests, suitable information about distances, interesting images and suitability between images and real conditions) ranged 3.01 to 4.00 . Though the performance of traveloka.com is good enough, it can still be maximized to be better. The rest seven indicators have very good performances as their means are greater than 4.00. Thus traveloka.com has very good perceptions in the consumer minds.

The highest performance of traveloka.com is in the methods of payment with mean of 4.22. Consumers have several choices to pay their online reservations since different consumers may have different needs and wants. Not all consumers have credit cards so they can make transactions using mobile or internet banking and the like. This easy payment makes them feel comfortable when making online transactions. In addition, the lowest performance of traveloka.com is the images displayed in the website which are sometimes not in accordance with the real conditions (mean 3.73). This is due to the fact that some hotels 
do not update the newest images in the website accordingly that can make consumers dissatisfied when they compare the images with the reality. Some consumers state that the room images look so spacious and clean; but in reality, the rooms are so narrow and not as clean as in the displayed images in the web.

Moreover, there are discrepancies between consumer expectations and perceptions in all indicators (Table 1); and these gaps are significant with $t$ value of 12.447 which is greater than $t$ table (2.201) and significance of 0.000 which is less than 0.050 (Table 2). The biggest gap is in the suitability of images in the website with the real conditions $(-0.69)$, while the least gap is in the easy way for consumers to get the necessary information (-0.30).

This study is also in accordance with by Febrianti et al. (2007) both studies show significant gaps between consumer expectations and perceptions when making hotel reservations. The object of this study is Online Travel Agent traveloka.com, whereas the object of the later study is a hotel website. The biggest gap in this study is in the displayed images in the website with the real conditons and the smallest gap is the easy use to get the necessary information. Whilst, the biggest gap of the later study is in the information of website management and the smallest gap is in information about consumer contact.

\section{Conclusion}

Consumer expectations are greater than consumer perceptions. There are some significant gaps between consumer expectations and perceptions in the twelve indicators of traveloka.com. The biggest gap is in the suitability of images displayed in the website with the real conditions as some consumers do not find the real conditions of the hotels as expected. Whereas, the least one is in the easy of consumers to get the necessary information in the website. This is due to the fact that sometimes it takes longer time to access the information. But as a whole, traveloka.com is still good enough in the minds of consumers.

Due to the gaps in this study, it is suggested that traveloka.com needs do the followings: 1) updating the latest hotel images as not to disappoint the consumers when they compare them with the reality, 2) providing more complete information about points of interests and attractions near the hotels so that consumers are able to plan their visit/trip, 3) providing more complete hotel description and addresses (e.g. telephone numbers, street numbers, post codes, etc.) that can be accessed in Google Maps or Waze easily,
4) maintaining more accurate or exact distance information about points of interests near the hotels, and 5) updating the latest hotel facilities if any.

\section{References}

Anandhita, Z. R., Kertahadi, \& Suyadi, I. (2014). Analisa atas desain website e-commerce pada ZGS game shop. Jurnal Administrasi Bisnis, 9(1), 1-10.

Bakar, A. R. A. \& Hashim, F. (2008). The determinants of online hotel reservations among university staffs. Communication of the IBIMA, 4 , 13-21.

Cosseboom, L. (2015). Why traveloka can be the first unicorn startup in Indonesia. Retrieved September 18, 2016, from https://id. Techinasi a.com/ traveloka-startup-unicorn-analisis-pasar.

English Oxford Living Dictionaries. (2016). Reservation. Retrieved September 19, 2016, from https://en.oxforddictionaries.com/definition/ reserve.

Erwinpetas. (2015). Comparison tiket.com vs traveloka. Retrieved October 21, 2016, from http:// yukjalan.net/perbandingan-tiket-com-vs-travelokal.

Febrianti, E., Setyawan, I.E., \& Thio, S. (2007). Analisis harapan dan persepsi konsumen terhadap dimensi website hotel bintang lima di surabaya. Jurnal Manajemen Perhotelan, 3(2), 102- 113.

Gozzali, S. (2013). Faktor-faktor yang mendorong masyarakat Surabaya dalam melakukan reservasi hotel secara online. Unpublished undergradduate thesis, Universitas Kristen Petra Surabaya.

Hartono, S. (2015). Traveloka vs tiket.com. Retrieved 22 October, 2016, from http://www.siwalan.co $\mathrm{m} / 2015 / 03 /$ traveloka-vs-tiketcom.html.

Horovitz, J. (2000). Seven secrets of service strategy. New Jersey: Prentice Hall.

Huizingh, E.K.R.E. (2000). The content of design and website: An empirical study. Information \& Management, 37, 123-134.

Janal, D.S. (2005). Online marketing handbook: How to sell, advertise, publicize, and your products and services on the internet and commercial online system. New York: Van Nostrand Reinhold.

Kamus Besar Bahasa Indonesia Online. (2015). Pesan. Retrieved September 19, 2016, from http://kbb i.web.id/pesan.

Kotler, P. \& Keller, K. L. (2006). Marketing management. International Edition. New Jersey: Pearson Prentice Hall. 
(2009). Marketing management: An asian perspective. New Jersey: Prentice Hall.

Law, R. \& Hsu, C. H. C. (2005). Customers' perceptions on the importance of hotel website dimensions and attributes. International Journal of Contemporary Hospitality Management, 17(6), 493-503.

Lovelock, C. H. \& Wright, L. K. (2007). Manajemen pemasaran. Jakarta: Indeks.

Nykiel, R. (2011). Marketing in the hospitality industry. Fifth Edition. America: American Hotel \& Lodging Educational Institute.

Phelan, K.V., Christodoulidou, N., \& Countryman, C. C. (2011). To book or not to book: The role of hotel website heuristics. Journal of Services Marketing, 25(2), 134-148.

Sosiawan, M. \& Sadhika, V. V. (2015). Analisa dimensi website yang mempengaruhi keputusan konsumen Surabaya dalam melakukan reservasi hotel secara online. Unpublished undergraduate thesis,Unversitas Kristen Petra.

Wearne, N. \& Baker, K. (2002). Hospitality marketing in the e-commerce age. Second Edition. Frenchs Forest, N.S.W.: Pearson Education.

Zeithaml, V., Bitner, M., \& Gremler, D. (2009). Services marketing integrating customer focus across the firm. Fifth Edition. New York: McGraw-Hill. 